\title{
Human Bocavirus in Patients with Respiratory Tract Infection
}

\author{
Jang Su Kim, M.D., Chae Seung Lim, M.D., Young Kee Kim, M.D., Kap No Lee, M.D., and Chang Kyu Lee, M.D. \\ Department of Laboratory Medicine, Korea University College of Medicine, Seoul, Korea
}

\begin{abstract}
Background: Human bocavirus ( $\mathrm{HBoV}$ ) is a newly identified viral pathogen, and its clinical epidemiology and significance in respiratory infections have not yet been completely elucidated. We investigated the prevalence of HBoV infection and the association between viral (HBoV) load and clinical features of the infection in patients of all age-groups.

Methods: Nasopharyngeal aspirates from patients with symptoms of respiratory infection were tested for presence of HBoV by using real-time polymerase chain reaction. $\mathrm{HBoV}$-positive patients were categorized into low- and high-viral-load groups using 1.0X $10^{6}$ copies $/ \mathrm{mL}$ as the threshold value of viral load.

Results: Detection rate of $\mathrm{HBoV}$ was $4.8 \%(\mathrm{~N}=93)$ in a total of 1,926 samples with peak incidence of infection being observed in patients aged 6-12 months. HBoV infection was more frequently observed in young children, especially, in children aged less than $5 \mathrm{yr}$, and the HBoV load decreased with increase in age. HBoV was codetected with other respiratory viruses in 17 (18.3\%) of the 93 HBoV-positive patients and 15 patients (88.2\%) belonged to the low-viral-load group. Patients infected with HBoV alone showed a higher viral load than those patients in whom HBoV was codetected with other respiratory viruses (median load, $3.78 \times 10^{5}$ copies/ $\mathrm{mL}$ vs. $1.94 \times 10^{4}$ copies $\left./ \mathrm{mL}, P=0.014\right)$. Higher pulse rate $(P=0.007)$ and respiratory rate $(P=0.021)$ were observed in patients with a high-viral-load.

Conclusions: Our results suggest that $\mathrm{HBoV}$ may be the causative agent of respiratory infection in the high-viral-load group.
\end{abstract}

Key Words: Bocavirus, Respiratory tract infections, Viral load

\section{INTRODUCTION}

Human bocavirus (HBoV) was newly discovered by $\mathrm{Al}-$ lander et al. [1] and was stated to be the possible causative agent of respiratory illness. Phylogenetic analysis of the complete genome of $\mathrm{HBoV}$ revealed that the virus is most closely related to canine minute virus and bovine parvovirus, which are members of the Bocavirus genus of the Parvoviridae family [1].

$\mathrm{HBoV}$ was found in $1.5-11.3 \%$ of respiratory samples investigated worldwide [2-5]. HBoV may be a causative agent

Received: August 26, 2010

Manuscript No: KJLM-10-127

Revision received: April 19, 2011

Accepted: May 9, 2011

Corresponding author: Chang Kyu Lee, M.D.

Department of Laboratory Medicine, Korea University Anam Hospital,

126-1 Anam-dong 5-ga, Seongbuk-gu, Seoul 136-075, Korea

Tel: +82-2-920-5381, Fax: +82-2-920-5429, E-mail: cklee@korea.ac.kr

ISSN 1598-6535 @ The Korean Society for Laboratory Medicine.

This is an Open Access article distributed under the terms of the Creative Commons Attribution Non-Commercial License (http://creativecommons.org/licenses/by-nc/3.0) which permits unrestricted non-commercial use, distribution, and reproduction in any medium, provided the original work is properly cited. of respiratory tract infections. However, some investigators argue that the association between $\mathrm{HBoV}$ and respiratory tract diseases remains unproven because of the high rate of codetection of $\mathrm{HBoV}$ with other respiratory pathogens [5]. Its clinical epidemiology and role in respiratory infection have not yet been fully elucidated.

Although recently it was found that $\mathrm{HBoV}$ could be cultured in differentiated human airway epithelial cells [6], routine viral culturing of $\mathrm{HBoV}$ remains difficult. Real-time PCR has been used to estimate viral load and its usefulness has been proved as an indicator of the degree of active viral infection, interactions between the virus and the host, and the role of viral reactivation or persistence in the progression of disease [7]. In this study, we investigated the epidemiology of $\mathrm{HBoV}$ and the clinical features of respiratory infection associated with $\mathrm{HBoV}$, especially in terms of $\mathrm{HBoV}$ load.

\section{MATERIALS AND METHODS}

\section{Materials}

From November 2005 to October 2006, 1,926 specimens 
from 1,815 patients were randomly selected among the 5,891 samples collected from patients referred to the Korea University Guro Hospital for screening for respiratory viruses. Among the patients, $59.0 \%$ were men, and the ages of the patients ranged from 1 day to $86.0 \mathrm{yr}$ (mean $=6.1 \mathrm{yr}$, median $=26$ months); children aged $5 \mathrm{yr}$ or less constituted $75.3 \%$ of the study population. The nasopharyngeal aspirates (NPAs) obtained from all patients were stored in a viral transport medium and quickly delivered to the laboratory by using wet ice. R-Mix culture system (Diagnostic HYBRIDS, Athens, $\mathrm{OH}, \mathrm{USA}$ ) was used to screen the samples for presence of 5 respiratory viruses (influenza A and B viruses, parainfluenza viruses, respiratory syncytial virus, and adenovirus).

\section{Methods}

\section{1) Conventional $P C R$}

Total nucleic acid was extracted from $100 \mu \mathrm{L}$ of the sample by using Instagene Matrix Kit (Bio-Rad, Hercules, CA, USA). PCR primers were designed using Beacon Designer software (Premier Biosoft International, Palo Alto, CA, USA) in the conserved region of the NS-1 coding region of the HBoV genome by using the HBoV ST2 sequence (Genbank accession number: DQ000496). The forward primer (5'-GCAAATCTCTTCTGGCTACACG-3') and the reverse primer (5'-CCTCTGCGATCTCTATATTGAAGG$\left.3^{\prime}\right)$ were targeted at a portion of the HBoV NS-1 gene. The conventional PCR reaction mixture consisted of $0.2 \mathrm{pg} / \mu \mathrm{L}$ forward and reverse primers, $2.5 \mathrm{mM}$ dNTPs, $50 \mathrm{mM} \mathrm{KCl}$, $1.5 \mathrm{mM} \mathrm{MgCl}_{2}, 5 \mathrm{U}$ of Taq polymerase, and $3 \mu \mathrm{L}$ of extracted DNA in a final volume of $25 \mu \mathrm{L}$. The PCR cycling conditions consisted of 35 cycles (involving reaction at $30 \mathrm{sec}$ at $94^{\circ} \mathrm{C}, 30 \mathrm{sec}$ at $60^{\circ} \mathrm{C}$, and $30 \mathrm{sec}$ at $72^{\circ} \mathrm{C}$ ) after the preheating step of $3 \mathrm{~min}$ at $94^{\circ} \mathrm{C}$. All the PCR products obtained from positive reactions were sequenced completely to confirm sequence specificity.

\section{2) Plasmid standard construction}

To obtain standard curves for absolute quantification, the PCR product of $\mathrm{HBoV}$ was cloned into a plasmid vector pGEM$^{\circledR}$-T Easy Vector (Promega, Madison, WI, USA), purified using a QIAprep mini prep kit (Qiagen Inc., Valencia, CA, USA), and quantified using UV spectroscopy (1 genomic copy $=5 \times 10^{-12} \mu \mathrm{g}$ ). Serial 10 -fold dilutions of the cloned plasmid were prepared to generate the standard curves.

\section{3) Real-time $P C R$}

Real-time PCR for viral load was performed on the specimens positive for HBoV by conventional PCR. A TaqMan probe (5'-ATGTTGCCGCCAGTAACTCCACCC-3') was labeled at the $5^{\prime}$ ends with the reporter molecule FAM and at the $3^{\prime}$ ends with Black Hole Quencher 1 (Biosearch Technologies, Inc., Novato, CA, USA). The assay was performed using Rotor-Gene 6000 (Corbett Life Science, Sydney, Australia) and the standard protocol of TaqMan universal PCR master mix (Applied Biosystems, Foster City, CA, USA); each $25 \mu \mathrm{L}$ sample of the reaction mixture contained $10 \mathrm{pg} /$ $\mu \mathrm{L}$ of the forward and the reverse primers and $3 \mu \mathrm{L}$ of the extracted DNA. Amplification conditions consisted of reactions for $3 \mathrm{~min}$ at $50^{\circ} \mathrm{C}, 3 \mathrm{~min}$ at $94^{\circ} \mathrm{C}$, and 40 cycles of 30 sec at $94^{\circ} \mathrm{C}, 30 \mathrm{sec}$ at $60^{\circ} \mathrm{C}$ and $30 \mathrm{sec}$ at $72^{\circ} \mathrm{C}$ maintained for $3 \mathrm{~min}$. Detection limit of real-time PCR for $\mathrm{HBoV}$ was $1.3 \times 10^{3}$ copies $/ \mathrm{mL}$, which corresponded to 33 copies per reaction.

\section{Statistical analysis}

Statistical analysis was performed using the SPSS software (version 10, SPSS Inc., Chicago, IL, USA), and graphs were prepared using Prism software (version 4.0, GraPad Software, Inc., San Diego, CA, USA). Mann-Whitney $U$ test, Chi-squared or Fisher's exact test were performed to assess the significance. A $P$ value $<0.05$ was considered statistically significant for all the tests.

\section{RESULTS}

A total of 1,926 samples of patients with respiratory symptoms were included in the present study. Ninety-three (4. 8\%) samples were found to be positive for HBoV by PCR and subsequent sequencing. Other respiratory viruses detected during the study period were as follows: influenza A virus (IFA), 56 patients (2.9\%); influenza B virus (IFB), 50 patients (2.6\%); parainfluenza viruses (PIV), 142 patients (7.4\%); respiratory syncytial virus (RSV), 97 patients (5.0\%); and adenovirus (ADV), 40 patients (2.1\%). HBoV was more prevalent in men (73.1\%) than in women $(P=0.005)$.

$\mathrm{HBoV}$ was detected in patients ranging from 3 months to $65.6 \mathrm{yr}$ (mean $=36.2$ months, median $=19$ months) with a peak prevalence between the ages of 6 and 12 months (8. $6 \%, 22 / 257)$. Children aged 5 yr or less constituted $92.5 \%$ (86/93) of the HBoV-positive patients (Table 1).

$\mathrm{HBoV}$ was detected in the samples obtained throughout the course of the study with the detection rate being the highest in June $(16 / 129,12.4 \%)$, followed by August $(9 / 110$, $8.2 \%)$ and May (13/162, 8.0\%). From April to June 2006, $43 \%$ of the HBoV-positive cases were observed (Fig. 1).

All the $93 \mathrm{HBoV}$-positive cases detected by conventional PCR were also confirmed by real-time PCR performed us- 
Table 1. Age distribution of human bocavirus-positive patients

\begin{tabular}{lccc}
\hline \multirow{2}{*}{ Age } & \multicolumn{3}{c}{$\mathrm{N}(\%)$ of human bocavirus-positive patients } \\
\cline { 2 - 4 } & Total & Low-viral-load group* & High-viral-load group* \\
\hline $0-6$ mon $(\mathrm{N}=291)$ & $3(1.0)$ & $2(0.7)$ & $1(0.3)$ \\
$6-12 \mathrm{mon}(\mathrm{N}=257)$ & $22(8.6)$ & $12(4.7)$ & $10(3.9)$ \\
$1-2 \mathrm{yr}(\mathrm{N}=368)$ & $31(8.4)$ & $15(4.1)$ & $16(4.3)$ \\
$2-3 \mathrm{yr}(\mathrm{N}=246)$ & $15(6.1)$ & $9(3.7)$ & $6(2.4)$ \\
$3-5 \mathrm{yr}(\mathrm{N}=289)$ & $15(5.2)$ & $13(4.5)$ & $2(0.7)$ \\
$5-10 \mathrm{yr}(\mathrm{N}=271)$ & $5(1.8)$ & $5(1.8)$ & 0 \\
$10-15 \mathrm{yr}(\mathrm{N}=61)$ & 0 & 0 & 0 \\
$>15 \mathrm{yr}(\mathrm{N}=143)$ & $2(1.4)$ & $2(1.4)$ & 0 \\
\hline Total $(\mathrm{N}=1,926)$ & $93(4.8)$ & $58(3.0)$ & $35(1.8)$ \\
\hline
\end{tabular}

*Human bocavirus positive patients were grouped into low-and high-viral-load groups using $1.0 \times 10^{6}$ copies $/ \mathrm{mL}$ as the threshold value.

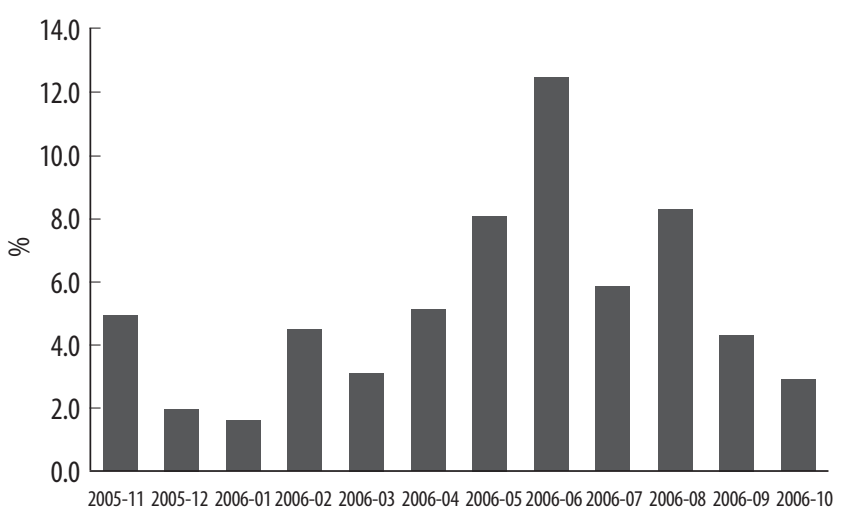

Fig. 1. Seasonal distribution of human bocavirus infection during the study period of $1 \mathrm{yr}$.

ing the TaqMan probe. The viral load detected in the HBoVpositive samples by using real-time PCR was in the range of $1.3 \times 10^{3}-4.6 \times 10^{9}$ copies $/ \mathrm{mL}$ (median, $1.82 \times 10^{5}$ copies/ $\mathrm{mL})$. The HBoV-positive cases were categorized in 2 groups: low-viral-load group (viral load $\leq 1.0 \times 10^{6}$ copies $/ \mathrm{mL}, \mathrm{N}=$ 58 ) and high-viral-load group (viral load $>1.0 \times 10^{6}$ copies/ $\mathrm{mL}, \mathrm{N}=35$ ) (Table 1). The HBoV-positive patients aged less than $3 \mathrm{yr}$ had a significantly higher viral load than that in the patients aged more than $3 \mathrm{yr}(P=0.001)$.

The other respiratory viruses found in 17 (18.3\%) of the total $\mathrm{HBoV}$-positive samples were as follows: IFA, 1 sample; IFB, 1 sample; PIV, 10 samples; RSV, 4 samples; and ADV, 1 sample. Most of the cases $(88.2 \%, 15 / 17)$ belonged to the low-viral-load group. RSV was isolated from the remaining 2 samples with $\mathrm{HBoV}$ copy numbers of $1.09 \times 10^{6}$ copies/ $\mathrm{mL}$ and $2.65 \times 10^{8}$ copies $/ \mathrm{mL}$.

Patients positive for $\mathrm{HBoV}$ alone had a higher viral load than that in the patients who were positive for both $\mathrm{HBoV}$ and another respiratory virus (median $3.78 \times 10^{5}$ copies $/ \mathrm{mL}$

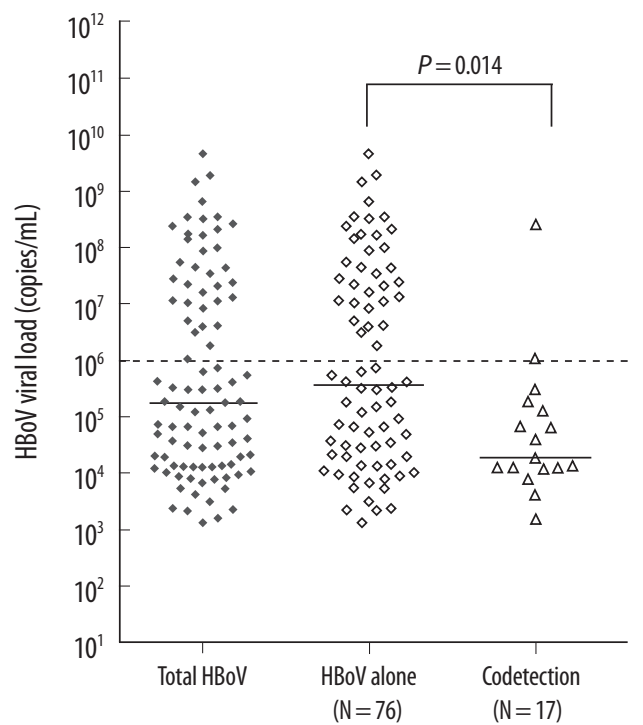

Fig. 2. HBoV viral load distribution of cases with $\mathrm{HBoV}$ infection alone and of cases in which $\mathrm{HBOV}$ was codetected with other viruses. The dotted line indicates the cut-off between the high-and the low-viral-load groups. The dashed lines indicate the median of each group.

Abbreviation: $\mathrm{HBoV}$, human bocavirus.

vs. $1.94 \times 10^{4}$ copies $\left./ \mathrm{mL}, P=0.014\right)$. A high-viral-load was almost exclusively seen in the HBoV-positive patients alone (94.3\%, 33/35) (Fig. 2).

The high-viral-load group had a significantly higher pulse rate and respiratory rate than the corresponding rates in the low-viral-load group $(P=0.007$ and $P=0.0231$, respectively; Table 2). Although the duration of hospital stay was not significantly different between the 2 groups (Table 2), in cases of patients with less than 10 days of hospital stay, the highviral-load group had a longer hospital stay than the low-viral-load group did $(5.2 \pm 1.5$ days vs. $4.1 \pm 1.4$ days, $P=0$. 009). Most of the other clinical characteristics had no significant correlation with the viral load of $\mathrm{HBoV}$. The HBoVpositive patients presented with cough $(80.6 \%)$, sputum (63.4\%), fever (62.4\%), rhinorrhea (50.5\%), crackle (44.1\%), wheezing (33.3\%), diarrhea (14.0\%), and dyspnea (6.5\%). No significant difference was observed in the $\mathrm{HBoV}$ viral loads in the cases of upper and lower respiratory tract infections $(P=0.077)$. Twenty-one out of 26 patients with underlying conditions had low-viral-loads.

Clinical examination of the $\mathrm{HBoV}$-positive patients showed pneumonia, bronchiolitis, bronchitis, croup, asthma, sinusitis, and pharyngotonsilitis (Fig. 3). $\mathrm{HBoV}$ was detected in $8.4 \%(\mathrm{~N}=48)$ and $5.6 \%(\mathrm{~N}=45)$ of the samples obtained from patients with and without pneumonia, respectively $(\mathrm{N}=572$ and 805, respectively; $P=0.049$ ). However, no significant difference was observed in the viral load between 
Table 2. Comparison of demographic and clinical characteristics of patients hospitalized for human bocavirus infection on the basis of viral loads*

\begin{tabular}{|c|c|c|c|}
\hline & $\begin{array}{l}\text { Low-viral-load } \\
\text { group }(\mathrm{N}=58)\end{array}$ & $\begin{array}{l}\text { High-viral-load } \\
\text { group }(\mathrm{N}=35)\end{array}$ & $P$ value \\
\hline $\begin{array}{l}\text { Duration of symptoms before } \\
\text { admission (days) }\end{array}$ & $5.4 \pm 6.5$ & $4.7 \pm 4.4$ & 0.586 \\
\hline Duration of hospitalization (days) & $5.6 \pm 3.0$ & $6.5 \pm 3.0$ & 0.146 \\
\hline Pulse rate (/min) & $121.3 \pm 16.4$ & $131.5 \pm 18.5$ & 0.007 \\
\hline Respiratory rate (/min) & $28.2 \pm 6.0$ & $31.9 \pm 9.8$ & 0.023 \\
\hline $\mathrm{WBC}\left(\times 10^{9}\right.$ cells $\left./ \mathrm{mL}\right)$ & $1.1 \pm 5.8$ & $1.3 \pm 5.6$ & 0.093 \\
\hline $\mathrm{ESR}(\mathrm{mm} / \mathrm{sec})$ & $29.1 \pm 21.1$ & $29.9 \pm 28.9$ & 0.879 \\
\hline C-reactive protein (mg/L) & $15.6 \pm 40.9$ & $11.2 \pm 25.1$ & 0.574 \\
\hline Fever & $38(65.5)$ & $20(57.1)$ & 0.509 \\
\hline Cough & $42(72.4)$ & $33(94.3)$ & 0.013 \\
\hline Dyspnea & $3(5.2)$ & $3(8.6)$ & 0.669 \\
\hline Sputum & $32(55.2)$ & $27(77.1)$ & 0.045 \\
\hline Rhinorrhea & $29(50.0)$ & $18(51.4)$ & 1.000 \\
\hline Diarrhea & $10(17.2)$ & $3(8.6)$ & 0.357 \\
\hline Abdominal pain & $22(37.9)$ & $16(45.7)$ & 0.517 \\
\hline Rale & $3(5.2)$ & $1(2.9)$ & 1.000 \\
\hline Wheezing & $17(29.3)$ & $14(40.0)$ & 0.365 \\
\hline Crackle & $26(44.8)$ & $15(42.9)$ & 1.000 \\
\hline Underlying conditions & $21(80.8)$ & $5(19.2)$ & $<0.001$ \\
\hline Abnormality on chest radiograph & $26(44.8)$ & $12(34.3)$ & 0.386 \\
\hline
\end{tabular}

*Data presented as mean \pm standard deviation or number (\%) of patients. Abbreviations: WBC, white blood cell; ESR, erythrocyte sedimentation rate.

the patients with and without pneumonia $(P>0.05)$.

\section{DISCUSSION}

Ninety-three $(4.8 \%)$ of the 1,926 nasopharyngeal aspirates obtained from patients of all age-groups were positive for $\mathrm{HBoV}$. Our detection rate is similar to that stated in other reports $[2,3,8]$. Generally, $\mathrm{HBoV}$ is detected in fewer than $8 \%$ of respiratory specimens $[1,8-13]$; however, higher detection rates ranging from $10.3 \%$ to $19 \%$ have been reported $[5,14,15]$.

To investigate the epidemiological association of respiratory infection with viral load, $\mathrm{HBoV}$-positive patients were categorized into low- and high-viral-load groups by using $1.0 \times 10^{6}$ copies $/ \mathrm{mL}$ as a threshold value. The detection rate of $\mathrm{HBoV}$ infection was at its peak in the first year of life (rate of detection, $8.6 \%$ between the ages of 6 and 12 months), as in the cases of RSV or PIV infection. Most of the HBoVpositive patients aged less than 3 yr belonged to the high-viral-load group. The detection rate was lower (1.5\%) in patients aged more than $10 \mathrm{yr}$, and these patients belonged exclusively to the low-viral-load group. $\mathrm{HBoV}$ is rarely de-

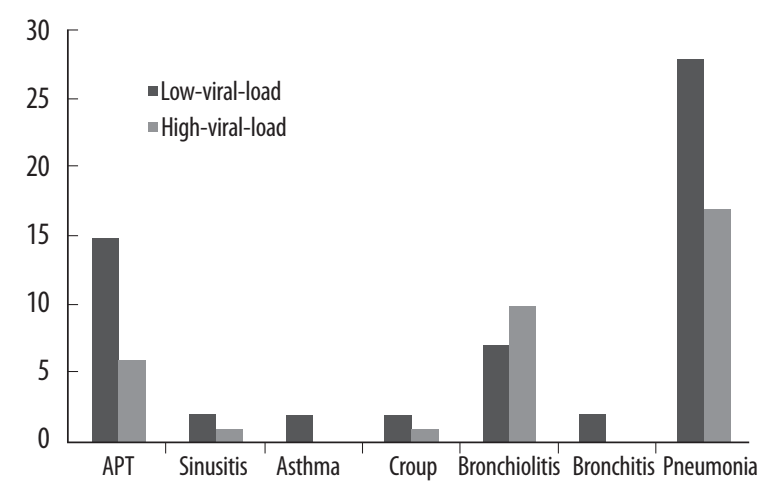

Fig. 3. Distribution of viral load in HBoV-positive patients according to diseases.

Abbreviation: $\mathrm{HBoV}$, human bocavirus.

tected in adults except in cases of immunosuppression [10, $16,17]$. The lower detection rate and viral load of HBoV in older patients may be attributed to immunity acquired from an infection at a younger age. A seroepidemiologic study of $\mathrm{HBoV}$ showed that $5.6-83.3 \%$ of children aged 6 months-3 yr were seropositive for $\mathrm{HBoV}$ [18]. Lau et al. [19] suggested that $\mathrm{HBoV}$ infection might develop only once because of the subsequent development of life-long immunity conferred by neutralizing antibodies produced in response to the infection.

The frequency of $\mathrm{HBoV}$ codetection with other respiratory viruses was $18.3 \%$ in the $\mathrm{HBoV}$-positive samples and was lower than the previously published data $[4,20]$. This difference in the codetection frequency is attributed to the different detection methods; molecular diagnostic methods were used for the detection of other respiratory viruses in the other studies whereas we used virus culturing. Among the $17 \mathrm{HBoV}$-positive patients who were also positive for infection with other viruses, 10 showed PIV infection. The high association of $\mathrm{HBoV}$ with PIV seems to be attributed to the high prevalence of PIV infection in 2006 (22.8\% in May). Interestingly, almost all cases (except two) positive for both $\mathrm{HBoV}$ and another respiratory virus belonged to the low-viral-load group. As the virus culture was used for the detection of major respiratory viruses, the isolated virus could be the main causative agent of respiratory illness. Therefore, the presence of low copy number of $\mathrm{HBoV}$, detected by molecular method, may indicate prolonged viral shedding or an asymptomatic infection. Recently, prolonged presence of HBoV in NPAs has been reported [21]. These results suggest that single $\mathrm{HBoV}$ infection in the high-viral-load group may play an active role in respiratory infection. These findings are consistent with a Norwegian study that reported detection of $\mathrm{HBoV}$ alone and a high-vi- 
ral-load were associated with respiratory tract infection [20]. In that study, patients with a high-viral-load in NPAs developed viremia more frequently than the patients with a moderate-or a low-viral-load did. In our study, HBoV-positive patients in the high-viral-load group showed significantly higher pulse rates and respiratory rates than the in the low-viral-load group. These findings also support the idea that a high-viral-load may be associated with a respiratory infection.

Previous studies have reported that $\mathrm{HBoV}$ infection was more prevalent among individuals who had other respiratory viruses [10, 22]. In a study performed in Hong Kong [19], a higher detection rate of $\mathrm{HBoV}$ was observed in NPAs positive for common respiratory viruses than in those that were negative for the same. However, in our study, similar detection rate of $\mathrm{HBoV}$ was observed in the samples positive and negative for other respiratory viruses in the R-mix culture (Data are not shown).

Previous studies showed that cases of $\mathrm{HBoV}$ infection were found throughout the year with a peak incidence rate in the winter season $[10,13,23]$. However, in our study, cases of $\mathrm{HBoV}$ infection were detected most frequently during the spring season. This finding is similar to those of reports from Korea [4, 24]. This seasonal difference in the incidence of $\mathrm{HBoV}$ infection may be attributed to regional and temporal differences.

Bastien et al. [8] suggested that risk factors for severe $\mathrm{HBoV}$ infection appear to be similar to those for RSV infection (prematurity, congenital heart disease, and asthma). Thirty percent (26/93) of the HBoV-positive patients had underlying conditions such as heart disease, asthma, allergy, preterm birth, and a history of convulsions; most of these patients (80.8\%) showed a low-viral-load. Persistent HBoV shedding for more than 1 month is observed in both respiratory and fecal specimens obtained from patients with significant underlying diseases [19]. Although these finding were not fully understood, it is postulated to be a result of underlying immunosuppression [19].

In summary, $\mathrm{HBoV}$ infection was more prevalent in young children. Patients positive for $\mathrm{HBoV}$ alone mainly constituted the high-viral-load group. Most of the HBoV-positive patients with infection caused by other respiratory viruses belonged to the low-viral-load group. These findings suggest that $\mathrm{HBoV}$ may be associated with a respiratory infection.

\section{Authors' Disclosures of Potential Conflicts of Interest}

No potential conflict of interest relevant to this article was reported.

\section{REFERENCES}

1. Allander T, Tammi MT, Eriksson M, Bjerkner A, Tiveljung-Lindell A, Andersson B. Cloning of a human parvovirus by molecular screening of respiratory tract samples. Proc Natl Acad Sci USA 2005; 102:12891-6.

2. Ma X, Endo R, Ishiguro N, Ebihara T, Ishiko H, Ariga T, et al. Detection of human bocavirus in Japanese children with lower respiratory tract infections. J Clin Microbiol 2006;44:1132-4.

3. Sloots TP, McErlean P, Speicher DJ, Arden KE, Nissen MD, Mackay IM. Evidence of human coronavirus HKU1 and human bocavirus in Australian children. J Clin Virol 2006;35:99-102.

4. Choi EH, Lee HJ, Kim SJ, Eun BW, Kim NH, Lee JA, et al. The association of newly identified respiratory viruses with lower respiratory tract infections in Korean children, 2000-2005. Clin Infect Dis 2006;43:585-92.

5. Weissbrich B, Neske F, Schubert J, Tollmann F, Blath K, Blessing K, et al. Frequent detection of bocavirus DNA in German children with respiratory tract infections. BMC Infect Dis 2006;6:109.

6. Dijkman R, Koekkoek SM, Molenkamp R, Schildgen O, van der Hoek L. Human bocavirus can be cultured in differentiated human airway epithelial cells. J Virol 2009;83:7739-48.

7. Mackay IM. Real-time PCR in the microbiology laboratory. Clin Microbiol Infect 2004; 10:190-212

8. Bastien N, Chui N, Robinson JL, Lee BE, Dust K, Hart L, et al. Detection of human bocavirus in Canadian children in a 1-year study. J Clin Microbiol 2007;45:610-3.

9. Kahn J. Human bocavirus: clinical significance and implications. Curr Opin Pediatr 2008;20:62-6.

10. Manning A, Russell V, Eastick K, Leadbetter GH, Hallam N, Templeton K, et al. Epidemiological profile and clinical associations of human bocavirus and other human parvoviruses. J Infect Dis 2006; 194:1283-90.

11. Kesebir D, Vazquez M, Weibel C, Shapiro ED, Ferguson D, Landry ML, et al. Human bocavirus infection in young children in the United States: molecular epidemiological profile and clinical characteristics of a newly emerging respiratory virus. J Infect Dis 2006; 194:1276-82.

12. Naghipour M, Cuevas LE, Bakhshinejad T, Dove W, Hart CA. Human bocavirus in Iranian children with acute respiratory infections. J Med Virol 2007;79:539-43.

13. Arden KE, McErlean P, Nissen MD, Sloots TP, Mackay IM. Frequent detection of human rhinoviruses, paramyxoviruses, coronaviruses, and bocavirus during acute respiratory tract infections. J Med Virol 2006;78:1232-40.

14. Allander T, Jartti T, Gupta S, Niesters HG, Lehtinen P, Osterback R, et al. Human bocavirus and acute wheezing in children. Clin Infect Dis 2007;44:904-10.

15. Kleines M, Scheithauer S, Rackowitz A, Ritter K, Häusler M. High prevalence of human bocavirus detected in young children with severe acute lower respiratory tract disease by use of a standard PCR protocol and a novel real-time PCR protocol. J Clin Microbiol 2007;45:1032-4.

16. Bastien N, Brandt K, Dust K, Ward D, Li Y. Human bocavirus infection, Canada. Emerg Infect Dis 2006;12:848-50.

17. Fry AM, Lu X, Chittaganpitch M, Peret T, Fischer J, Dowell SF, et al. Human bocavirus: a novel parvovirus epidemiologically associ- 
ated with pneumonia requiring hospitalization in Thailand. J Infect Dis 2007;195:1038-45.

18. Endo R, Ishiguro N, Kikuta H, Teramoto S, Shirkoohi R, Ma X, et al. Seroepidemiology of human bocavirus in Hokkaido prefecture, Japan. J Clin Microbiol 2007;45:3218-23.

19. Lau SK, Yip CC, Que TL, Lee RA, Au-Yeung RK, Zhou B, et al. Clinical and molecular epidemiology of human bocavirus in respiratory and fecal samples from children in Hong Kong. J Infect Dis 2007;196:986-93.

20. Christensen A, Nordbø SA, Krokstad S, Rognlien AG, Døllner H. Human bocavirus in children: mono-detection, high-viral-load and viraemia are associated with respiratory tract infection. J Clin Virol 2010;49:158-62.

21. Blessing K, Neske F, Herre U, Kreth HW, Weissbrich B. Prolonged detection of human bocavirus DNA in nasopharyngeal aspirates of children with respiratory tract disease. Pediatr Infect Dis J 2009; 28:1018-9.

22. Franz A, Adams O, Willems R, Bonzel L, Neuhausen N, Schweizer-Krantz S, et al. Correlation of viral load of respiratory pathogens and co-infections with disease severity in children hospitalized for lower respiratory tract infection. J Clin Virol 2010;48:23945.

23. Arnold JC, Singh KK, Spector SA, Sawyer MH. Human bocavirus: prevalence and clinical spectrum at a children's hospital. Clin Infect Dis 2006;43:283-8.

24. Chung JY, Han TH, Kim SW, Kim CK, Hwang ES. Detection of viruses identified recently in children with acute wheezing. J Med Virol 2007;79:1238-43. 